\title{
Prevalence, awareness and control of diabetes in the Seychelles and relationship with excess body weight
}

\author{
David Faeh1,2, Julita William³ ${ }^{3}$ Luc Tappy², Eric Ravussin ${ }^{4}$ and \\ Pascal Bovet*1,3
}

Address: ${ }^{1}$ University Institute for Social and Preventive Medicine (IUMSP), Lausanne, Switzerland, ${ }^{2}$ Department of Physiology, University of Lausanne, Lausanne, Switzerland, ${ }^{3}$ Ministry of Health, Victoria, Republic of Seychelles and ${ }^{4}$ Pennington Biomedical Research Centre, Baton Rouge, LA, USA

Email: David Faeh - david.faeh@ifspm.uzh.ch; Julita William - williamb913@hotmail.com; Luc Tappy - luc.tappy@unil.ch; Eric Ravussin - ravusse@pbrc.edu; Pascal Bovet* - pascal.bovet@chuv.ch

* Corresponding author

Published: 19 July 2007

BMC Public Health 2007, 7:163 doi:10.1 I86/147|-2458-7-163
Received: 31 December 2006

Accepted: 19 July 2007

This article is available from: http://www.biomedcentral.com//47I-2458/7//63

(c) 2007 Faeh et al; licensee BioMed Central Ltd.

This is an Open Access article distributed under the terms of the Creative Commons Attribution License (http://creativecommons.org/licenses/by/2.0), which permits unrestricted use, distribution, and reproduction in any medium, provided the original work is properly cited.

\begin{abstract}
Background: The evidence for a "diabesity" epidemic is accumulating worldwide but populationbased data are still scarce in the African region. We assessed the prevalence, awareness and control of diabetes (DM) in the Seychelles, a rapidly developing country in the African region. We also examined the relationship between body mass index, fasting serum insulin and DM.
\end{abstract}

Methods: Examination survey in a sample representative of the entire population aged 25-64 of the Seychelles, attended by 1255 persons (participation rate of $80.2 \%$ ). An oral glucose tolerance test (OGTT) was performed in individuals with fasting blood glucose between 5.6 and $6.9 \mathrm{mmol} / \mathrm{l}$. Diabetes mellitus (DM), impaired fasting glucose (IFG) and impaired glucose tolerance (IGT) were defined along criteria of the ADA. Prevalence estimates were standardized for age.

Results: The prevalence of DM was II.5\% and 54\% of persons with DM were aware of having DM. Less than a quarter of all diabetic persons under treatment were well controlled for glycemia $(\mathrm{HbAlc})$, blood pressure or LDL-cholesterol. The prevalence of IGT and IFG were respectively $10.4 \%$ and $24.2 \%$. The prevalence of excess weight $\left(\mathrm{BMI} \geq 25 \mathrm{~kg} / \mathrm{m}^{2}\right)$ and obesity $\left(\mathrm{BMI} \geq 30 \mathrm{~kg} / \mathrm{m}^{2}\right)$ was respectively $60.1 \%$ and $25.0 \%$. Half of all DM cases in the population could be attributed to excess weight.

Conclusion: We found a high prevalence of DM and pre-diabetes in a rapidly developing country in the African region. The strong association between overweight and DM emphasizes the importance of weight control measures to reduce the incidence of DM in the population. High rates of diabetic persons not aware of having DM in the population and insufficient cardiometabolic control among persons treated for DM stress the need for intensifying health care for diabetes. 


\section{Background}

It is estimated that diabetes mellitus (DM) accounts currently for $5.2 \%$ of all deaths worldwide [1]. The number of people with DM is expected to double from 175 million in 2000 to 353 million in 2030 [2]. The largest increase is expected to occur in developing countries, with 305 million individuals likely to have DM by 2030 [2].

The prevalence of DM in adults varies markedly between different populations, e.g. $2.6 \%$ in Nigeria [3], $18 \%$ in Mauritius [4], and more than 50\% in Pima Indians in the U.S. [5]. These differences have been related to unfavorable trends in factors such as overweight and sedentary habits, as demonstrated in longitudinal, ecological and migration studies [4-6] and to interactions between environmental and genetic factors when individuals become exposed to an obesogenic environment [4,7].

In developing countries, the prevalence of diabetes is markedly higher in urban than rural areas (e.g. $2.0 \%$ vs. $0.8 \%$ in Cameroon in 1999 or $14 \%$ vs. 5\% in Egypt in 1995) $[8,9]$. There is also a gradient across socio-economic development stages, e.g. a prevalence of DM in African individuals of 2\% in Cameroon, $9 \%$ in Jamaica, $11 \%$ in Trinidad and Tobago and $15 \%$ in Manchester $[8,10]$, which further emphasizes the role of environment factors in populations of same genetic origin. However, data on the prevalence, awareness and control of DM remain limited in the African region.

Based on a population-based survey, we assessed the prevalence, awareness and control of diabetes (DM) in the Republic of Seychelles, a rapidly developing country in the African region. We also examined the relationship between body mass index, fasting serum insulin and DM and the proportion of all diabetic persons in the population that could be attributed to excess body weight.

\section{Methods}

The Republic of Seychelles consists of over 100 islands located in the Indian Ocean about $2000 \mathrm{~km}$ east of Kenya and $2000 \mathrm{~km}$ north of Mauritius, in the African region. Approximately $90 \%$ of the population of Seychelles lives on the main island (Mahé) and most of the remaining population resides on two nearby islands (Praslin and La Digue). Although intermarriage has blurred racial differences in many Seychellois, it can be considered that approximately two thirds of the population is of predominantly African descent, $15 \%$ is of predominantly Caucasian, Indian or Chinese descent, and a fifth is mixed between these various groups. The population of Seychelles can be considered as fairly urbanized in view of the high density of the population and the facts that a large proportion of the population commutes to the capital for work and three quarters of workers are employed in serv- ices $[11,12]$. The national gross domestic product per capita, in real terms, rose from US\$ 2927 in 1980 to US\$ 5239 in 2004 [13], reflecting booming tourism and industrial fishing industries. In Seychelles, cardiovascular disease and AIDS currently account for $38 \%$ and $1 \%$ of all deaths, respectively [11]. Health care (inclusive medications) is provided free of charge to all inhabitants. The disease burden related to diabetes is significant in Seychelles (e.g. a majority of lower limb amputations and a third of all persons under hemodialysis are related to diabetes), although the precise diabetes-related disease burden has not been systematically determined yet.

A population-based examination survey for cardiovascular risk factors was conducted in 2004 under the auspices of the Ministry of Health of the Republic of Seychelles. The sampling frame consisted of a sex- and age- stratified random sample of the population aged 25-64. Eligible individuals were selected from a computerized database derived from population censuses (last in 2002) thereafter regularly updated by civil status authorities. Eligible participants were invited to participate through a personal letter requesting them to attend designated survey centers on a particular date, fasting, between 7:30 and 11:00 am and informing them that snacks would be provided on the study center. Participants were free to participate and gave informed written consent. The survey was approved by the research and ethical board of the Ministry of Health of the Republic of Seychelles.

A structured questionnaire was administered by trained survey officers. The questions assessed, among other items, if participants were "ever told by a doctor that they had DM" and if they "were currently under treatment for DM". If treatment was reported, participants were considered to have "known" DM. Family history of DM was defined for participants who reported DM among a first degree parents or siblings. Weight was measured with electronic scales to $0.2 \mathrm{~kg}$ precision (Seca, Hamburg, Germany) and height was measured with fixed stadiometers to $0.5 \mathrm{~cm}$ precision (Seca). BMI was calculated as weight divided by height squared $\left(\mathrm{kg} / \mathrm{m}^{2}\right)$. Blood pressure (BP) refers to the average of the second and third of three measurements (mercury sphygmomanometer, cuff size adjusted to arm circumference).

Venous blood glucose was measured with a Cholestec LDX, a point-of-care analyzer which is a reliable alternative to conventional laboratory devices [14]. The Cholestec instrument separates blood cells from plasma and measurements are therefore made on plasma. If glucose was $\geq 5.6 \mathrm{mmol} / \mathrm{l}$, another measurement was carried out a few minutes later on capillary blood (Bayer, Ascentia Elite [15]) and the mean of both readings was used. Of note, the Ascentia Elite automatically adjusts reading to 
plasma values. The difference between the first measurement (Cholestec) and the second measurement (Ascentia Elite) was as small as $-0.15 \mathrm{mmol} / \mathrm{l}$. Individuals who had FBG $\geq 5.6 \mathrm{mmol} / \mathrm{l}$ and $<7.0 \mathrm{mmol} / \mathrm{l}$ and were not aware of having DM were submitted to an oral glucose tolerance test (OGTT) using $75 \mathrm{~g}$ glucose dissolved in $300 \mathrm{ml}$ water and capillary glucose (Ascentia Elite) was measured 120 minutes later (2hBG). Glycated hemoglobin (HbA1c) was measured in known or new cases of DM using a point-ofcare analyzer (DCA 2000, Bayer). The DCA 2000 has been recommended for measurement of HbA1c outside of the laboratory [16].

Categories of impaired glucose regulation were based on the 2004 criteria of the American Diabetes Association [17]. DM was defined as plasma FBG $\geq 7.0 \mathrm{mmol} / \mathrm{l}, 2 \mathrm{hBG}$ $\geq 11.1 \mathrm{mmol} / \mathrm{l}$ or current history of antidiabetic medication. IFG refers to FBG of 5.6-6.9 mmol/l. IGT was defined as FBG $<7.0 \mathrm{mmol} / \mathrm{l}$ and $2 \mathrm{hBG}$ of $7.8-11.0$ $\mathrm{mmol} / \mathrm{l}$. Normal glucose tolerance (NGT) was defined as $2 \mathrm{hBG}<7.8 \mathrm{mmol} / \mathrm{l}$. Normal fasting glucose (NFG) refers to FBG values $<5.6 \mathrm{mmol} / \mathrm{l}$. Since subjects with NFG were not tested for 2-hour glucose, we cannot determine DM based on $2 \mathrm{hBG} \geq 11.1 \mathrm{mmol} / \mathrm{l}$ and NFG.

Serum was obtained within 2 hours of blood collection and immediately frozen to $-20^{\circ} \mathrm{C}$. Fasting serum insulin (FSI) was measured at the University of Lausanne using commercial RIA kits (LINCO Research Inc, Missouri, USA). HOMA-IR (homeostasis model assessment of insulin resistance) was calculated as [FSI $(\mu \mathrm{U} / \mathrm{ml}) \times$ FBG $(\mathrm{mmol} / \mathrm{l})] / 22.5$ [18]. Blood lipids were measured using standard methods (Hitachi 917 instrument and Roche reagents) and low-density lipoprotein cholesterol (LDLC) calculated with the Friedewald formula.

Overall estimates in the population aged 25-64 were standardized to the new age distribution of the World Health Organization [19], using weighted "svy" commands in Stata. Differences were tested with the chisquare test and the t-test, respectively. For medians interquartile ranges were calculated. Increases in mean FSI across categories of impaired glucose regulation and BMI categories were tested with the Cuzik trend test. The association between DM and body mass index categories was analyzed with logistic regression adjusted for age and sex and weighted for the age-stratified sampling frame ("svylogit"). We used a model aggregating men and women since the interaction of BMI with sex was not significant. We calculated the proportions of all DM cases in the population that could be attributable to overweight and obesity (population attributable fraction, PAF) using the weighted "aflogit" command in Stata. PAF is conceptually computed as $\mathrm{P}(\mathrm{RR}-1) /[1+\mathrm{P}(\mathrm{RR}-1)]$, where $\mathrm{P}$ is the prevalence of excess weight in the population [20] and RR is the risk ratio of the exposure (excess weight) on the outcome (DM). RR was estimated with the adjusted odds ratio (OR) derived from the multivariate logistic regression models and confidence intervals were based on asymptotic approximation [20]. Analyses were performed with Stata 8.2 and $p$ values less than 0.05 were considered significant.

\section{Results}

1255 out of 1565 (80.3\%) eligible individuals participated. Age-standardized mean values and prevalence rates of selected characteristics are presented in Table 1. Mean and median BMI and prevalence of overweight and obesity were higher in women than in men $(\mathrm{p}<0.001)$. Mean FBG was similar in men and in women. Mean and median FSI were higher in women than in men $(p<0.001)$.

Table 2 shows the prevalence of different categories of impaired glucose regulation. The prevalence of DM was particularly high in the oldest age group (55-64) in both sexes. The prevalence of IFG was higher in men than in women ( $p<0.001)$. Since the measurement of FBG alone may leave some DM persons undetected, an OGTT was performed in individuals with FBG between 5.6-6.9 $\mathrm{mmol} / \mathrm{l}$. Using OGTT results for the diagnosis of DM (i.e. $2 \mathrm{hBG} \geq 11.1 \mathrm{mmol} / \mathrm{l}$ ) in addition to other criteria for DM, the overall prevalence of DM increased by $2.1 \%$ (absolute difference) or $22 \%$ (relative difference). The prevalence of IGT did not differ significantly $(p>0.05)$ between genders. Of note, the prevalence of combined IFG/IGT is necessarily equal to the prevalence of IFG in our study since OGTT was performed in all subjects with IFG (i.e. FBG between 5.6 and $6.9 \mathrm{mmol} / \mathrm{l}$ ). Based on all three criteria for DM, the prevalence of DM standardized for the actual population of Seychelles in 2004 (i.e. not adjusted to the WHO standard population) was $10.2 \%$ overall $(95 \% \mathrm{CI}$ : 8.6-11.9); men: $10.2 \%$ (7.7-12.7), women: 10.3 (8.012.6). The slightly lower prevalence using actual age distribution in Seychelles vs. the WHO age distribution reflects that the proportion of young vs. old people is slightly larger in the actual population of Seychelles than in the WHO standard age distribution.

Table 3 shows the odds ratios relating excess body weight to DM and the proportions of DM cases in the population that could be attributable to overweight and obesity, by sex and overall. Estimates are standardized to the WHO age distribution and regression models are also adjusted for age. The prevalence of overweight and obesity was higher in women than in men $(p<0.001)$. DM was strongly associated with excess body weight (e.g. OR in both men and women: 2.6 for BMI more vs. less than 25 $\mathrm{kg} / \mathrm{m}^{2}$ ). The OR of DM associated with overweight and obesity appearing in the table were virtually unchanged if underweight (BMI $<18.5 \mathrm{~kg} / \mathrm{m}^{2}$, less than $6 \%$ ) was also 
Table I: Age-standardized means and medians of selected characteristics by sex

\begin{tabular}{|c|c|c|c|c|c|c|c|}
\hline \multirow[b]{2}{*}{$\mathrm{n}$} & & \multicolumn{2}{|c|}{ Men } & \multicolumn{2}{|c|}{ Women } & \multicolumn{2}{|c|}{ All } \\
\hline & & 568 & & 687 & & 1255 & \\
\hline \multicolumn{8}{|l|}{ Age (years) } \\
\hline $25-34 t$ & $\%$ & 22.2 & & 21.7 & & 21.9 & \\
\hline $35-44 \dagger$ & $\%$ & 23.6 & & 25.6 & & 24.7 & \\
\hline $45-54 \dagger$ & $\%$ & 27.8 & & 26.3 & & 27.0 & \\
\hline $55-64 \dagger$ & $\%$ & 26.4 & & 26.4 & & 26.4 & \\
\hline Mean age & years & 45.3 & $(0.5)$ & 45.1 & $(0.4)$ & 45.2 & $(0.3)$ \\
\hline Mean age & years & 42.1 & $(0.5)$ & 41.9 & $(0.4)$ & 42.0 & $(0.3)$ \\
\hline Mean body mass index & $\mathrm{kg} / \mathrm{m}^{2}$ & 25.5 & $(0.2)$ & 28.3 & $(0.2)$ & 26.9 & $(0.2)$ \\
\hline Median body mass index & $\mathrm{kg} / \mathrm{m}^{2}$ & 25.2 & $(6.3)$ & 27.8 & $(8.5)$ & 26.4 & (7.4) \\
\hline Prevalence underweight & $\%$ & 4.6 & $(0.9)$ & 3.3 & $(0.7)$ & 4.0 & $(0.6)$ \\
\hline Prevalence excess weight & $\%$ & 51.9 & $(2.1)$ & 68.3 & $(1.9)$ & 60.1 & $(1.4)$ \\
\hline Prevalence obesity & $\%$ & 15.0 & $(1.5)$ & 35.1 & $(1.8)$ & 25.0 & $(1.2)$ \\
\hline Mean fasting blood glucose & $\mathrm{mmol} / \mathrm{l}$ & 6.0 & $(0.1)$ & 5.7 & $(0.1)$ & 5.9 & $(0.1)$ \\
\hline Median fasting blood glucose & $\mathrm{mmol} / \mathrm{l}$ & 5.5 & $(0.8)$ & 5.3 & $(0.7)$ & 5.4 & $(0.8)$ \\
\hline Mean fasting serum insulin & $\mathrm{pmol} / \mathrm{l}$ & 81.0 & $(3.1)$ & 96.6 & $(2.8)$ & 88.8 & $(2.1)$ \\
\hline Median fasting serum insulin & $\mathrm{pmol} / \mathrm{l}$ & 63.0 & $(48.6)$ & 76.2 & $(55.2)$ & 69.6 & (52.2) \\
\hline Mean HOMA-IR & & 4.1 & $(0.2)$ & 4.5 & $(0.2)$ & 4.3 & $(0.1)$ \\
\hline Median HOMA-IR & & 2.7 & $(2.4)$ & 3.1 & $(2.7)$ & 2.9 & $(2.5)$ \\
\hline
\end{tabular}

Standard errors and inter-quartile ranges are indicated between brackets for means and medians, respectively. Except for age, all estimates are standardized for age [19].

Underweight: BMI $<18.5 \mathrm{~km} / \mathrm{m}^{2}$; excess weight: $\mathrm{BMI} \geq 25 \mathrm{~km} / \mathrm{m}^{2}$; obesity: $\mathrm{BMI} \geq 30 \mathrm{~kg} / \mathrm{m}^{2}$.

HOMA-IR: homeostasis model assessment of insulin resistance.

† Crude estimates. Other estimates are standardized for age.

Table 2: Prevalence of diabetes, impaired fasting glucose and impaired glucose tolerance (percent and $95 \%$ confidence interval) and proportion of diabetic persons aware of having diabetes

\begin{tabular}{|c|c|c|c|c|c|c|c|c|c|c|c|}
\hline & \multicolumn{4}{|c|}{ Men } & \multicolumn{4}{|c|}{ Women } & \multicolumn{3}{|c|}{$25-64$} \\
\hline & $25-34$ & $35-44$ & $45-54$ & $55-64$ & $25-34$ & $35-44$ & $45-54$ & $55-64$ & Men & Women & All \\
\hline $\mathrm{n}$ & 126 & 134 & 158 & 150 & 149 & 176 & 181 & 181 & 568 & 687 & 1255 \\
\hline \multicolumn{12}{|l|}{ Diabetes (DM) } \\
\hline DM (2 criteria) & $\begin{array}{c}0.8 \\
(0-2.3)\end{array}$ & $\begin{array}{c}9.7 \\
(4.7-15)\end{array}$ & $\begin{array}{c}12.7 \\
(7.5-18)\end{array}$ & $\begin{array}{c}22.0 \\
(15-29)\end{array}$ & $\begin{array}{c}2.0 \\
(0.2-2.3)\end{array}$ & $\begin{array}{c}4.6 \\
(1.5-7.6)\end{array}$ & $\begin{array}{c}11.6 \\
(6.9-16)\end{array}$ & $\begin{array}{c}26.5 \\
(20-33)\end{array}$ & $\begin{array}{c}9.6 \\
(7.4-12)\end{array}$ & $\begin{array}{c}9.1 \\
(7.2-11)\end{array}$ & $\begin{array}{c}9.4 \\
(7.9-11)\end{array}$ \\
\hline DM (3 criteria) & $\begin{array}{c}0.8 \\
(0-2.3)\end{array}$ & $\begin{array}{c}9.7 \\
(4.7-15)\end{array}$ & $\begin{array}{c}14.6 \\
(9.1-20)\end{array}$ & $\begin{array}{c}27.3 \\
(20-35)\end{array}$ & $\begin{array}{c}3.4 \\
(0.5-2.9)\end{array}$ & $\begin{array}{c}6.3 \\
(2.7-9.8)\end{array}$ & $\begin{array}{c}14.9 \\
(9.7-20)\end{array}$ & $\begin{array}{c}34.3 \\
(27-4 I)\end{array}$ & $\begin{array}{c}11.0 \\
(8.7-13)\end{array}$ & $\begin{array}{c}12.1 \\
(9.9-14)\end{array}$ & $\begin{array}{c}11.5 \\
(9.9-13)\end{array}$ \\
\hline \multicolumn{12}{|c|}{ Impaired fasting glucose } \\
\hline IFG & $\begin{array}{c}16.0 \\
(9.6-22)\end{array}$ & $\begin{array}{c}35.1 \\
(27-43)\end{array}$ & $\begin{array}{c}42.4 \\
(35-50)\end{array}$ & $\begin{array}{c}32.9 \\
(25-40)\end{array}$ & $\begin{array}{c}5.4 \\
(1.7-3.6)\end{array}$ & $\begin{array}{c}13.6 \\
(8.6-19)\end{array}$ & $\begin{array}{c}26.5 \\
(20-33)\end{array}$ & $\begin{array}{c}37.0 \\
(30-44)\end{array}$ & $\begin{array}{c}30.4 \\
(27-34)\end{array}$ & $\begin{array}{c}18.0 \\
(15-2 \mid)\end{array}$ & $\begin{array}{c}24.2 \\
(22-26)\end{array}$ \\
\hline \multicolumn{12}{|l|}{ Glucose tolerance } \\
\hline NGT $(2$ hBG <7.8) & $\begin{array}{c}12.8 \\
(6.9-19)\end{array}$ & $\begin{array}{c}23.9 \\
(16-31)\end{array}$ & $\begin{array}{c}21.5 \\
(15-28)\end{array}$ & $\begin{array}{c}10.7 \\
(5.8-16)\end{array}$ & $\begin{array}{c}2.7 \\
(0.1-2.6)\end{array}$ & $\begin{array}{c}2.3 \\
(0.1-4.5)\end{array}$ & $\begin{array}{c}8.8 \\
(4.7-13)\end{array}$ & $\begin{array}{c}12.7 \\
(7.8-18)\end{array}$ & $\begin{array}{c}17.6 \\
(14-21)\end{array}$ & $\begin{array}{c}5.7 \\
(4.1-7.3)\end{array}$ & $\begin{array}{c}11.6 \\
(9.8-14)\end{array}$ \\
\hline IGT (2hBG 7.8-1I.0) & $\begin{array}{c}3.2 \\
(0.1-6.3)\end{array}$ & $\begin{array}{c}10.5 \\
(5.3-16)\end{array}$ & $\begin{array}{c}18.4 \\
(12-24)\end{array}$ & $\begin{array}{c}17.5 \\
(11-24)\end{array}$ & $\begin{array}{c}2.0 \\
(0-2.3)\end{array}$ & $\begin{array}{c}9.7 \\
(5.3-14)\end{array}$ & $\begin{array}{c}14.4 \\
(9.2-20)\end{array}$ & $\begin{array}{c}17.1 \\
(12-23)\end{array}$ & $\begin{array}{c}11.2 \\
(8.7-14)\end{array}$ & $\begin{array}{c}9.6 \\
(7.5-12)\end{array}$ & $\begin{array}{c}10.4 \\
(8.8-12)\end{array}$ \\
\hline $\mathrm{DM}(2 \mathrm{hBG} \geq 1 \mathrm{I} . \mathrm{I})$ & 0.0 & $\begin{array}{c}0.8 \\
(0-2.2)\end{array}$ & $\begin{array}{c}2.5 \\
(0.1-5.0)\end{array}$ & $\begin{array}{c}4.7 \\
(1.3-8.1)\end{array}$ & $\begin{array}{c}0.7 \\
(0-1.3)\end{array}$ & $\begin{array}{c}1.7 \\
(0-3.6)\end{array}$ & $\begin{array}{c}3.3 \\
(0.7-5.9)\end{array}$ & $\begin{array}{c}7.2 \\
(3.4-1 \mathrm{I})\end{array}$ & $\begin{array}{c}1.6 \\
(0.7-2.5)\end{array}$ & $\begin{array}{c}2.7 \\
(1.6-3.8)\end{array}$ & $\begin{array}{c}2.1 \\
(1.4-2.9)\end{array}$ \\
\hline \multicolumn{12}{|c|}{ Aware of DM (among DM) } \\
\hline & 0.0 & $\begin{array}{c}30.8 \\
(4.7-56)\end{array}$ & $\begin{array}{c}45.0 \\
(23-67)\end{array}$ & $\begin{array}{c}60.6 \\
(44-77)\end{array}$ & 0.0 & $\begin{array}{c}50.0 \\
(13-87)\end{array}$ & $\begin{array}{c}61.9 \\
(4 I-83)\end{array}$ & $\begin{array}{c}64.6 \\
(51-78)\end{array}$ & $\begin{array}{c}47.1 \\
(35-59)\end{array}$ & $\begin{array}{c}61.5 \\
(50-73)\end{array}$ & $\begin{array}{c}53.9 \\
(46-62)\end{array}$ \\
\hline
\end{tabular}

FBG: fasting blood glucose; IFG: impaired fasting glucose; $2 \mathrm{hBG:} \mathrm{blood} \mathrm{glucose} 2$ hours after oral tolerance test; NGT: normal glucose tolerance; IGT: impaired glucose tolerance; DM: diabetes mellitus.

DM (2 criteria): FBG $\geq 7.0 \mathrm{mmol} / \mathrm{l}$ or history of treatment for DM.

DM ( 3 criteria): $F B G \geq 7.0 \mathrm{mmol} / /$, history of treatment for $D M$, or $2 \mathrm{hBG} \geq 11 . \mathrm{mmol} / \mathrm{l}$.

Oral glucose tolerance test was administered to all individuals with FBG of 5.6-6.9 mmol/l without previous history of diabetes.

Overall prevalence estimates are standardized for age [19]. 
factored in the analysis (the reference BMI category being then $18.5-24.9 \mathrm{~kg} / \mathrm{m}^{2}$ ). The proportion of all DM cases in the entire population that could be attributed to excess weight was $49 \%$ (95\%: 35\%-61\%). By using lower cut off values to define the reference BMI category -as used in other studies [21]-, the proportions of all cases of DM in the population that are attributable to excess weight increased to $58 \%$ (95\% CI: $56 \%-60 \%$ ) for a BMI cut off set at $\geq 24 \mathrm{~kg} / \mathrm{m}^{2}$ and to $73 \%(71 \%-74 \%)$ for a BMI cut off set at $\geq 23 \mathrm{~kg} / \mathrm{m}^{2}$.

In a separate model, the odds for having DM were 2.4 $(1.7-3.5)$ times higher in persons with family history of DM compared to those without it. This OR for family history of DM was virtually identical whether BMI was included in multivariate analysis or not and whether models were run in all participants, men or women. Adjusting for age, sex and BMI, the proportion of all DM cases in the population that could be attributable to family history of DM was 25\% (14-35\%).

Figure 1 shows that mean FSI increased gradually across both categories of BMI and categories of impairment of glucose metabolism (i.e. NFG, IFG, IGT, DM). In separate analyses adjusted for age and sex (analyses not shown), the same relationships were found between FSI and both categories of impaired glucose regulation and BMI categories ( $\mathrm{p}$ for trend $<0.001$ for both). In these analyses, DM patients who were on insulin treatment $(n=10)$ were excluded. Analyses with HOMA-IR instead of FSI showed same patterns of association with categories of BMI and glucose metabolism impairment.

Figure 2 shows, among all persons reporting current antidiabetic treatment $(n=80)$, the proportions who achieved different levels of blood glucose (based on HbA1c), BP and LDL-cholesterol. Less than a quarter of diabetic persons under treatment achieved recommended treatment targets for any of these three considered cardiometabolic conditions, i.e. HbA1c $<7, \mathrm{BP}<130 / 80 \mathrm{mmHg}$, and LDLcholesterol $<2.6 \mathrm{mmol} / \mathrm{l}$. Less than $50 \%$ of treated patients achieved levels HbA1c $<8, \mathrm{BP}<140 / 90 \mathrm{mmHg}$ and LDL-cholesterol $<3.5 \mathrm{mmol} / \mathrm{l}$. Almost $40 \%$ had HbA1c $\geq 10$ and approximately $20 \%$ had BP $\geq 160 / 100$ or LDL cholesterol $\geq 5 \mathrm{mmol} / \mathrm{l}$. The prevalence of high blood pressure and hypercholesterolemia in this population were published earlier [22].

\section{Discussion}

We found a high prevalence of DM in a rapidly developing country in the African region, a substantial proportion of persons unaware of DM in the population, limited cardiometabolic control among treated diabetic persons, and a strong association of DM with excess weight. These findings in Seychelles add to the few population-based data on DM available in the African region and may be representative of other countries experiencing rapid socio-economic development and concurrent lifestyle changes.

The prevalence of DM is higher in Seychelles than in predominantly rural African regions such as Nigeria [3], Cameroon [23] or Tanzania [24] but as high as in urban settings in South Africa [25] and Egypt [9]. The prevalence of DM in Seychelles is however lower than in the island of Mauritius [4] despite larger BMI in the population of Seychelles than in Mauritius. The difference between these two neighbor islands of similar economic development may partly relate to their different ethnic composition (predominantly African in Seychelles and predominantly Indian in Mauritius) since Indian descent is a known risk factor for DM $[4,26]$. Compared to non African countries, the prevalence of DM in the Seychelles is similar to estimates in urban Saudi Arabia [27], several regions of Europe [28], the United States [29] and urban India [6] but higher than in Mongolia [30], Bangladesh [31], the

Table 3: Relationship between categories of body mass index (BMI) and diabetes and proportion of diabetic persons in the entire population that is attributable to overweight and obesity ( $95 \%$ confidence intervals in brackets)

\begin{tabular}{|c|c|c|c|c|c|c|c|c|c|}
\hline & \multicolumn{3}{|c|}{ Men } & \multicolumn{3}{|c|}{ Women } & \multicolumn{3}{|c|}{ All } \\
\hline & Prevalence (\%) & Odds ratio* & PAF (\%) & Prevalence (\%) & Odds ratio* & PAF (\%) & Prevalence (\%) & Odds ratio* & PAF (\%) \\
\hline \multicolumn{10}{|l|}{ Overweight } \\
\hline (BMI: $25-29 \mathrm{~kg} / \mathrm{m}^{2}$ ) & $37(33-4 I)$ & $2.1(1.9-2.2)$ & $26(16-36)$ & $33(30-37)$ & $2.6(2.3-3.0)$ & $20(12-26)$ & $35(32-38)$ & $3.5(3.2-3.8)$ & $23(|4-3|)$ \\
\hline \multicolumn{10}{|l|}{ Obesity } \\
\hline$\left(\mathrm{BMI} \geq 30 \mathrm{~kg} / \mathrm{m}^{2}\right)$ & $15(12-18)$ & $2.6(2.4-2.9)$ & $17(1 \mid-23)$ & $35(32-29)$ & $4.5(4.0-5.1)$ & $36(25-45)$ & $25(23-28)$ & $3.3(2.0-5.5)$ & $26(15-36)$ \\
\hline \multicolumn{10}{|l|}{ Overweight or obesity } \\
\hline$\left(\mathrm{BMI} \geq 25 \mathrm{~kg} / \mathrm{m}^{2}\right)$ & $52(48-56)$ & $2.2(2.1-2.4)$ & $43(29-55)$ & $68(64-72)$ & $3.6(3.2-4.1)$ & $56(4 \mid-67)$ & $60(57-63)$ & $2.6(2.4-2.8)$ & $49(35-6 I)$ \\
\hline
\end{tabular}

All models are adjusted for age.

Estimates are standardized for age [19].

BMI: body mass index.

PAF: population attributable fraction.

* reference category: $\mathrm{BMI}<25 \mathrm{~kg} / \mathrm{m}^{2}$. 


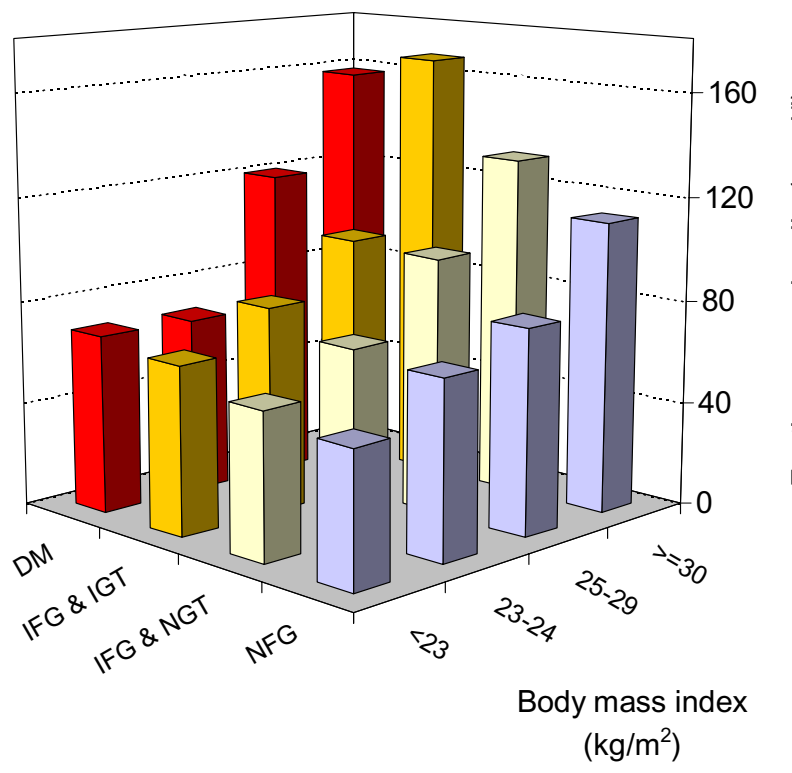

Figure I

Mean fasting serum insulin concentration by categories of body mass index (BMI) and categories of glucose metabolism impairment. NFG: normal fasting glucose; IFG: impaired fasting glucose; NGT: normal glucose tolerance; IGT: impaired glucose tolerance; DM: diabetes mellitus (excluding patients on insulin treatment).

Philippines [32], Spain [33], Australia [34], Turkey [35] and rural Saudi Arabia [27].

A few factors in our study may tend to over or underestimate the true prevalence of DM in the population. Possible biases for underestimation are several. First we did not include individuals older than 64 years, an age group in which the prevalence of DM is likely to be particularly high $[4,29,36,37]$. Second, we did not perform an OGTT in individuals with FBG $<5.6 \mathrm{mmol} / \mathrm{l}$ and we could have missed a few DM cases in persons with normal fasting glucose but pathologically high post meal levels. The number of such cases is however expected to be small [38]. Third, underestimation might also have occurred if non participation was related to diabetes-related diseases (e.g. leg wounds, renal failure, stroke, etc). On the other hand, overestimation may have occurred if some persons with elevated FBG were not fasting. This bias was minimized as persons who reported not to be fasting were invited to attend the survey on another day. Also, elevated fasting blood glucose was not repeated on a separate day. Overall, it is possible that factors that over or underestimate the prevalence of DM might balance each other and our prevalence estimates may be close to the true prevalence of DM in the adult population.

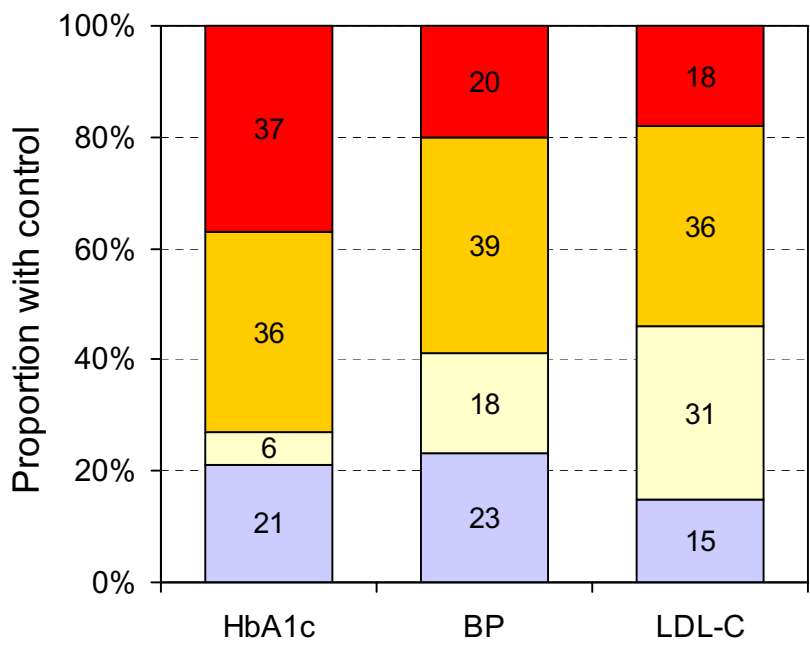

Figure 2

Level of control of blood glucose (HbA I c: glycatedhemoglobin), blood pressure (BP) and low-density lipoprotein cholesterol (LDL-C) in all participants receiving hypoglycemic treatment $(n=80)$. Cut off values for control categories are $<7.0,7.0-7.9,8-9.9, \geq 10$ for

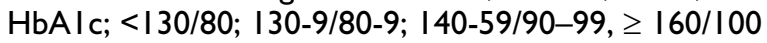
$\mathrm{mmHg}$ for BP; and <2.6, 2.6-3.4, 3.5-4.9, $\geq 5 \mathrm{mmol} / \mathrm{l}$ for LDL-cholesterol. Blue: within recommended treatment targets.

The high prevalence of IFG and/or IGT suggests that the DM epidemic has not yet plateaued in Seychelles. Indeed, IGT [39] and IFG [40] are strong predictors of DM [41] and these pre-diabetes conditions may occur in up to $60 \%$ of individuals several years before DM develops [42]. It has been reported that in the USA, where the prevalence of IFG and IGT is respectively $26 \%$ and $15 \%$, approximately $25 \%$ of individuals with IFG/IGT will progress to diabetes, 50\% will remain in their abnormal glycemic state, and $25 \%$ will revert to normal glucose tolerance (NGT) over a period of 3 to 5 years [43]. Hence, the substantially high proportion of pre-diabetes in Seychelles predicts a further increase in the prevalence of DM over the next few years, consistent with projections in other African countries in epidemiological transition $[23,26,36]$.

While the proportion of all diabetes cases in the population who are aware of having DM ("aware") is approximately 50\%, similar low proportions (about 50\%) are also typically found in middle- or high-income countries such as Egypt [9], Saudi Arabia [27], Spain [33] and the U.S. [44]. Such low figures emphasize the difficulty to identify a disease (DM) that is most often silent for many years after onset. 
We found that a large proportion of diabetic persons under anti-diabetic treatment had levels of blood sugar (as assessed by HbA1c), blood pressure, and LDL-cholesterol above the recommended therapeutic targets. Limited clinical control of DM is also found in high income western countries such as the USA [45]. In the USA, only $37 \%$ of DM patients had HbA1c levels $<7.0 \%$, only $35.8 \%$ achieved target blood pressure $(<130 / 80 \mathrm{mmHg})$ and $51.8 \%$ of DM patients had hypercholesterolemia [45]. This further illustrates the great difficulty in achieving and sustaining good control of blood glucose, blood pressure and blood lipids in chronic diseases such as DM. In addition, limited cardiometabolic control is known to be even more difficult to achieve in DM patients who are overweight -a frequent occurrence- because of underlying insulin resistance $[45,46]$.

DM was associated strongly with overweight, independent of age, sex and family history of DM. This relationship has been found consistently in other populations $[27,32,33,35,47]$ and, for example, $90 \%$ of new DM cases among both African and white Americans had BMI $\geq 23$ $\mathrm{kg} / \mathrm{m}^{2}$ [21]. In our study, half of all DM cases could be attributed to overweight or obesity. This proportion rose to $73 \%$ if normal weight was considered for BMI $<23 \mathrm{~kg} /$ $\mathrm{m}^{2}$ instead of BMI $<25 \mathrm{~kg} / \mathrm{m}^{2}$. In a Taiwanese cohort as much as $71 \%$ of DM cases were attributable to a BMI $\geq 25$ $\mathrm{kg} / \mathrm{m}^{2}[48]$.

It is important to attempt to determine if the prevalence rates of DM and overweight (i.e. "diabesity") has increased over time in order to anticipate epidemiological trends and inform health care policy. The prevalence of DM was assessed for the first time in 1989 in the population of Seychelles [49] and it was found that 3.4\% of men and $4.6 \%$ of women had DM. Using the same criteria in 1989 and 2004 (i.e. known diabetes and/or elevated fasting blood glucose) and the same age standardization (new WHO age distribution [20]) the prevalence of DM significantly increased between the two years in men (from $6.2 \%$ to $9.6 \%$ ) and in women (from 6.1\% to $9.1 \%$ ). Since the survey methods were not identical in 1989 and 2004 (e.g. glucometers), there is a degree of uncertainty in these trend estimates. However, a true increase in the prevalence of DM over time is consistent with the large increase in obesity in men (from $4.3 \%$ to $15.0 \%$ ) and women (from $27.9 \%$ to $35.1 \%$ ). Increasing prevalence of overweight/obesity in the population in the interval is likely related to increasingly sedentary behaviors and larger caloric intake. Currently, more than $75 \%$ of workers are employed in services (vs. only 20\% in industry and 5\% in agriculture) $[11,12]$. The number of both private cars and passengers transported by public buses has doubled in the past 10 years (figures from the Licensing Authority and the Seychelles Public Transport Company, respec- tively). On the other hand, food balance sheets indicate that calorie availability per capita has increased substantially in Seychelles, e.g. from $1800 \mathrm{kcal}$ in $1965,2300 \mathrm{kcal}$ in the late $1980 \mathrm{~s}$, and above $2400 \mathrm{kcal}$ in the early $2000 \mathrm{~s}$ [50]. The proportion of carbohydrates has decreased over time $(74 \%$ of total calories in 1965 and $55 \%$ in 2000) while the proportion of fats has increased $(16 \%$ in 1965 and $32 \%$ in 2000) [50]. The production of carbonated soft drinks by the main local manufacturer has tripled in the past 25 years (figures from Seychelles Breweries Ltd).

\section{Conclusion}

The prevalence of DM in Seychelles has reached or exceeded levels typically found in several middle- or highincome countries. The strong association between DM and excess body weight emphasizes the importance of weight control interventions at a population level as a cornerstone strategy to curb the "diabesity" epidemic [51]. From a clinical perspective, the substantial proportion of persons unaware of having DM calls for improved early detection of diabetic persons. The high proportion of treated diabetic persons with insufficient cardiometabolic control stresses the need for intensifying clinical care to diabetic patients in order to minimize complications [52].

\section{Abbreviations}

DM: diabetes mellitus; FBG: fasting blood glucose; IFG: impaired fasting glucose; IGT: impaired glucose tolerance; HOMA: homeostasis model assessment of insulin resistance; 2-hour OGTT: oral glucose tolerance test; 2hBG: 2hour postload blood glucose; BP: blood pressure; LDL-C: low-density lipoprotein cholesterol; HbA1c: glycated haemoglobin; PAF: population attributable fraction.

\section{Competing interests}

The author(s) declare that they have no competing interests.

\section{Authors' contributions}

DF lead the analysis of the data and the write up of the manuscript. JW coordinated several aspects of the survey and reviewed the manuscript. LT performed insulin assays and reviewed the manuscript. ER assisted in the interpretation of data and reviewed the manuscript. PB lead the organization of the survey, assisted with the analysis and interpretation of the data and with the write up of the manuscript. All authors read and approved the final manuscript.

\section{Acknowledgements}

We thank the survey officers, particularly George Madeleine, Bharathi Viswanathan and Vanessa Lafortune as well as all the participants to the survey. Partial funding came from the Ministry of Health, Republic of Seychelles; the University Institute of Social and Preventive Medicine and the Department of Physiology of the University of Lausanne, Switzerland; the Institute of Clinical Chemistry and Hematology, St. Gallen, Switzerland; the 
World Health Organization, Brazzaville; and the Seychelles Marketing Board, Air Seychelles, and SkyChef Ltd (Seychelles).

\section{References}

I. Roglic G, Unwin N, Bennett PH, Mathers C, Tuomilehto J, Nag S, Connolly $\mathrm{V}$, King $\mathrm{H}$ : The burden of mortality attributable to diabetes: realistic estimates for the year 2000. Diabetes Care 2005, 28:2130-2135

2. Yach D, Stuckler D, Brownell KD: Epidemiologic and economic consequences of the global epidemics of obesity and diabetes. Nat Med 2006, 12:62-66.

3. Okesina AB, Oparinde DP, Akindoyin KA, Erasmus RT: Prevalence of some risk factors of coronary heart disease in a rural Nigerian population. East Afr Med J 1999, 76:212-2I6.

4. Soderberg S, Zimmet P, Tuomilehto J, de Courten M, Dowse GK, Chitson P, Gareeboo H, Alberti KG, Shaw JE: Increasing prevalence of Type 2 diabetes mellitus in all ethnic groups in Mauritius. Diabet Med 2005, 22:6I-68.

5. Ravussin E, Valencia ME, Esparza J, Bennett PH, Schulz LO: Effects of a traditional lifestyle on obesity in Pima Indians. Diabetes Care 1994, I 7:1067-1074.

6. Ramachandran A: Epidemiology of type 2 diabetes in Indians. J Indian Med Assoc 2002, 100:425-427.

7. Neel JV: Diabetes mellitus: a "thrifty" genotype rendered detrimental by "progress"? Am J Hum Genet 1962, I 4:353-362.

8. Mbanya JC, Cruickshank JK, Forrester T, Balkau B, Ngogang JY, Riste L, Forhan A, Anderson NM, Bennett F, Wilks R: Standardized comparison of glucose intolerance in west African-origin populations of rural and urban Cameroon, Jamaica, and Caribbean migrants to Britain. Diabetes Care 1999, 22:434-440.

9. Herman WH, Ali MA, Aubert RE, Engelgau MM, Kenny SJ, Gunter EW, Malarcher AM, Brechner RJ, Wetterhall SF, DeStefano F: Diabetes mellitus in Egypt: risk factors and prevalence. Diabet Med 1995, I2:||26-||3|.

10. Sartorelli DS, Franco LJ: Trends in diabetes mellitus in Brazil: the role of the nutritional transition. Cad Saude Publica 2003, 19 Suppl I:S29-36.

II. CIA World Factbook 2005 [https://www.cia.gov/cia/publications/ factbook/index.html].

12. World Health Organisation - Regional Office for Africa 2005 [http://www.afro.who.int]

13. Statistical abstracts. Management \& Information Systems Division, Victoria, Seychelles, 2004.

14. Shemesh T, Rowley KG, Shephard M, Piers LS, O'Dea K: Agreement between laboratory results and on-site pathology testing using Bayer DCA2000+ and Cholestech LDX point-ofcare methods in remote Australian Aboriginal communities. Clin Chim Acta 2006, 367:69-76.

15. Rheney CC, Kirk JK: Performance of three blood glucose meters. Ann Pharmacother 2000, 34:317-321.

16. St John A, Davis TM, Goodall I, Townsend MA, Price CP: Nursebased evaluation of point-of-care assays for glycated haemoglobin. Clin Chim Acta 2006, 365:257-263.

17. American Diabetes Association: Diagnosis and classification of diabetes mellitus. Diabetes Care 2004, 27:S5-SIO.

18. Matthews DR, Hosker JP, Rudenski AS, Naylor BA, Treacher DF, Turner RC: Homeostasis model assessment: insulin resistance and beta-cell function from fasting plasma glucose and insulin concentrations in man. Diabetologia 1985, 28:4I2-4I9.

19. Ahmad OB, Boschi-Pinto C, Lopez AD, Murray CJL, Lozano R, Inoue $M$ : Age standardization of rates: a new WHO standard. GPE Discussion Paper Series: No3 I 2005, EIP/GPE/EBD, World Health Organization:

20. Greenland S, Drescher K: Maximum likelihood estimation of the attributable fraction from logistic models. Biometrics 1993, 49:865-872.

21. Stevens J, Couper D, Pankow J, Folsom AR, Duncan BB, Nieto FJ, Jones D, Tyroler HA: Sensitivity and specificity of anthropometrics for the prediction of diabetes in a biracial cohort. Obes Res 2001, 9:696-705.

22. Bovet P, Shamlaye C, Gabriel A, Riesen W, Paccaud F: Prevalence of cardiovascular risk factors in a middle-income country and estimated cost of a treatment strategy. BMC Public Health 2006, 6:9.
23. Mbanya JC, Ngogang J, Salah JN, Minkoulou E, Balkau B: Prevalence of NIDDM and impaired glucose tolerance in a rural and an urban population in Cameroon. Diabetologia 1997, 40:824-829.

24. McLarty DG, Swai AB, Kitange HM, Masuki G, Mtinangi BL, Kilima PM, Makene WJ, Chuwa LM, Alberti KG: Prevalence of diabetes and impaired glucose tolerance in rural Tanzania. Lancet 1989, I:87|-875.

25. Levitt NS, Steyn K, Lambert EV, Reagon G, Lombard CJ, Fourie JM, Rossouw K, Hoffman M: Modifiable risk factors for Type 2 diabetes mellitus in a peri-urban community in South Africa. Diabet Med 1999, 16:946-950.

26. Soderberg S, Zimmet $P$, Tuomilehto J, de Courten M, Dowse GK Chitson P, Stenlund H, Gareeboo H, Alberti KG, Shaw J: High incidence of type 2 diabetes and increasing conversion rates from impaired fasting glucose and impaired glucose tolerance to diabetes in Mauritius. J Intern Med 2004, 256:37-47.

27. Al-Nuaim AR: Prevalence of glucose intolerance in urban and rural communities in Saudi Arabia. Diabet Med 1997, 1 4:595-602

28. Group DECODES: Age- and sex-specific prevalences of diabetes and impaired glucose regulation in I 3 European cohorts. Diabetes Care 2003, 26:61-69.

29. Harris MI, Flegal KM, Cowie CC, Eberhardt MS, Goldstein DE, Little RR, Wiedmeyer HM, Byrd-Holt DD: Prevalence of diabetes, impaired fasting glucose, and impaired glucose tolerance in U.S. adults. The Third National Health and Nutrition Examination Survey, 1988-1994. Diabetes Care 1998, 2 I:518-524.

30. Suvd J, Gerel B, Otgooloi H, Purevsuren D, Zolzaya H, Roglic G, King $\mathrm{H}$ : Glucose intolerance and associated factors in Mongolia: results of a national survey. Diabet Med 2002, 1 9:502-508.

31. Sayeed MA, Mahtab H, Akter Khanam P, Abdul Latif Z, Keramat Ali SM, Banu A, Ahren B, Azad Khan AK: Diabetes and impaired fasting glycemia in a rural population of Bangladesh. Diabetes Care 2003, 26: 1034-1039.

32. Baltazar JC, Ancheta CA, Aban IB, Fernando RE, Baquilod MM: Prevalence and correlates of diabetes mellitus and impaired glucose tolerance among adults in Luzon, Philippines. Diabetes Res Clin Pract 2004, 64: I07-I I5.

33. Tamayo-Marco B, Faure-Nogueras E, Roche-Asensio MJ, Rubio-Calvo E, Sanchez-Oriz E, Salvador-Olivan JA: Prevalence of diabetes and impaired glucose tolerance in Aragon, Spain. Diabetes Care 1997, 20:534-536.

34. Dunstan DW, Zimmet PZ, Welborn TA, de Courten MP, Cameron AJ, Sicree RA, Dwyer T, Colagiuri S, Jolley D, Knuiman M, Atkins R, Shaw JE: The rising prevalence of diabetes and impaired glucose tolerance: the Australian Diabetes, Obesity and Lifestyle Study. Diabetes Care 2002, 25:829-834.

35. Satman I, Yilmaz T, Sengul A, Salman S, Salman F, Uygur S, Bastar I, Tutuncu Y, Sargin M, Dinccag N, Karsidag K, Kalaca S, Ozcan C, King $\mathrm{H}$ : Population-based study of diabetes and risk characteristics in Turkey: results of the turkish diabetes epidemiology study (TURDEP). Diabetes Care 2002, 25: I55 I-I556.

36. Motala AA: Diabetes trends in Africa. Diabetes Metab Res Rev 2002, I Suppl 3:SI4-20.

37. Qiao Q, Hu G, Tuomilehto J, Nakagami T, Balkau B, Borch-Johnsen K, Ramachandran A, Mohan V, lyer SR, Tominaga M, Kiyohara Y, Kato I, Okubo K, Nagai M, Shibazaki S, Yang Z, Tong Z, Fan Q, Wang B, Chew SK, Tan BY, Heng D, Emmanuel S, Tajima N, Iwamoto Y, Snehalatha C, Vijay V, Kapur A, Dong Y, Nan H, Gao W, Shi H, Fu F: Ageand sex-specific prevalence of diabetes and impaired glucose regulation in II Asian cohorts. Diabetes Care 2003, 26: $1770-1780$.

38. Gabir MM, Hanson RL, Dabelea D, Imperatore G, Roumain J, Bennett $\mathrm{PH}$, Knowler WC: The 1997 American Diabetes Association and 1999 World Health Organization criteria for hyperglycemia in the diagnosis and prediction of diabetes. Diabetes Care 2000, 23:1108-1112.

39. Edelstein SL, Knowler WC, Bain RP, Andres R, Barrett-Connor EL, Dowse GK, Haffner SM, Pettitt DJ, Sorkin JD, Muller DC, Collins VR, Hamman RF: Predictors of progression from impaired glucose tolerance to NIDDM: an analysis of six prospective studies. Diabetes 1997, 46:701-710.

40. Kim DJ, Cho NH, Noh JH, Kim HJ, Choi YH, Jung JH, Min YK, Lee MS, Lee MK, Kim KW: Fasting plasma glucose cutoff value for the prediction of future diabetes development: a study of mid- 
dle-aged Koreans in a health promotion center. J Korean Med Sci 2005, 20:562-565.

41. Meigs JB, Muller DC, Nathan DM, Blake DR, Andres R: The natural history of progression from normal glucose tolerance to type 2 diabetes in the Baltimore Longitudinal Study of Aging. Diabetes 2003, 52:|475-| 484.

42. Unwin N, Shaw J, Zimmet P, Alberti KG: Impaired glucose tolerance and impaired fasting glycaemia: the current status on definition and intervention. Diabet Med 2002, 19:708-723.

43. Davidson MB, Genuth S, Fagan TF, Palangio MA: American Diabetes Association Consensus Statement on IFG and IGT. Clinical Insights in Diabetes 2007:2-3.

44. Jaber LA, Brown MB, Hammad A, Nowak SN, Zhu Q, Ghafoor A, Herman WH: Epidemiology of diabetes among Arab Americans. Diabetes Care 2003, 26:308-3I3.

45. Saydah SH, Fradkin J, Cowie CC: Poor control of risk factors for vascular disease among adults with previously diagnosed diabetes. JAMA 2004, 291:335-342.

46. Brown AS: Lipid management in patients with diabetes mellitus. Am / Cardiol 2005, 96:26E-32E.

47. Sullivan PW, Morrato EH, Ghushchyan V, Wyatt HR, Hill JO: Obesity, inactivity, and the prevalence of diabetes and diabetesrelated cardiovascular comorbidities in the U.S., 2000-2002. Diabetes Care 2005, 28:1599-1603.

48. Hwang LC, Tsai CH, Chen TH: Overweight and obesity-related metabolic disorders in hospital employees. J Formos Med Assoc 2006, 105:56-63.

49. Tappy L, Bovet P, Shamlaye C: Prevalence of diabetes and obesity in the adult population of the Seychelles. Diabet Med 1991, 8:448-452.

50. Food and Agriculture Organization of the United Nations (FAO), Food Balance Sheets [http://faostat.fao.org/site/502/ default.aspx]

51. Astrup A, Finer N: Redefining type 2 diabetes: 'diabesity' or 'obesity dependent diabetes mellitus'? Obes Rev 2000, 1:57-59.

52. Standards of medical care in diabetes. Diabetes Care 2005, 28 SuppI I:S4-S36.

\section{Pre-publication history}

The pre-publication history for this paper can be accessed here:

http://www.biomedcentral.com/1471-2458/7/163/pre

pub
Publish with Bio Med Central and every scientist can read your work free of charge

"BioMed Central will be the most significant development for disseminating the results of biomedical research in our lifetime. "

Sir Paul Nurse, Cancer Research UK

Your research papers will be:

- available free of charge to the entire biomedical community

- peer reviewed and published immediately upon acceptance

- cited in PubMed and archived on PubMed Central

- yours - you keep the copyright 